\title{
AN EXPERIMENTAL STUDY OF COMPUTER-BASED NEGOTIATION IN PROPERTY DEVELOPMENT PROCESSES
}

\author{
Datuk Ary Adriansyah SAMSURA a,*, Adrian van DEEMEN b, \\ Erwin van der KRABBEN a,c, Rob van der HEIJDEN a \\ ${ }^{a}$ Department of Geography, Planning and Environment, Radboud University Nijmegen, Thomas van \\ Aquinostraat 3, P.O. Box 9108, 6500 HK Nijmegen, Netherlands \\ ${ }^{b}$ Department of Strategic Management, Radboud University Nijmegen, Thomas van Aquinostraat 3, \\ P.O. Box 9108, 6500 HK Nijmegen, Netherlands \\ ${ }^{c}$ Built Environment Research Institute, University of Ulster, Belfast, United Kingdom
}

Received 29 January 2013; accepted 23 August 2013

\begin{abstract}
This paper reports an experiment based on the model of bilateral sequential bargaining over the distribution of a certain value in a laboratory setting within a real specific context of property development in the Netherlands. We have involved only property development professionals as participants in the experiment who have experience with the context. We have also extended the experiment into three different negotiation games distinguished by the availability of information to the participants: a negotiation game with incomplete information, asymmetric information, and complete information. We have found in this experiment that the availability of information could affect the plausibility to reach an agreement, particularly due to a restricted communication setting. This study also provides evidences that it is in the negotiators' concern to reach an agreement with a fair outcome, which is defined here as the equilibrium, regardless the availability of the information to them.
\end{abstract}

KEYWORDS: Negotiation; Experiment; Strategic decision making behaviour; Land and real estate development

\section{INTRODUCTION}

It has been well-acknowledged that the practice of property or land and real estate development almost always involves negotiation processes, for instance between a municipality and a private developer, between a municipality or a private developer and a landowner, between a private developer and an institutional investor, et cetera. (Healey et al. 1995; Ennis 1997; Urbanavičienè et al. 2009a). The concern in those negotiations may vary. It could be about the price to be paid for a piece of land, the contribution of a private developer to infrastructure costs (value capturing), the price to be paid for acquiring a completed building, or else (Adams 1994; Xu et al. 2012). A successful negotiation, including bargaining and making a compromise among stakeholders involved, clearly plays a crucial role in urban planning in general and to attain a successful land and real estate development project in particular. A failure to make

\footnotetext{
* Corresponding author. E-mail: d.samsura@fm.ru.nl
}

a good bargain among stakeholders involved will therefore most likely hamper land and real estate development processes.

The study of negotiations as a bargaining process has received much attention in different fields of disciplines. It mainly aims to help people to negotiate in a more effective way (Bazerman 1986; Thompson 1990). There has also been a growing interest in experimental work on bargaining (e.g. Ochs, Roth 1989; Weg, Zwick 1999; Binmore et al. 2007), aiming to observe bargainers' behaviour in a negotiation process. Although the literature on negotiation and bargaining in the field of urban planning and land and real estate development is extensive (see e.g. Ennis 1997; Farthing, Ashley 2002; Ruming 2009; Urbanavičienè et al. 2009b), experimental studies of negotiation and bargaining in this field are almost absent (with, however, a few notable exceptions, including Black, Diaz 1996; Arentze, Timmermans 2003). The lack of attention to experimental approaches in negotiation analysis related to urban planning and land 
development is perhaps understandable because an experimental setting might not be able to capture all the complexities of the processes which are also very much context-driven. However, the relevance of negotiation experiments with real-life situations, especially related to urban planning and land development, is not trivial. Because of the difficulty in specifying the influence of unique factors of stakeholders' behaviour on the outcome of the negotiation due to its intrinsic complexity, an experiment could be an appropriate tool to observe and to control the stakeholders' responses under specific conditions. Hence, it might provide general insights about the behaviour of stakeholders in a negotiation process and may even predict the outcome of negotiation processes under certain conditions. Moreover, an experimental approach also allows us to create a coherent structure for a line of argumentation. The setup of an experiment allows the researcher to systematically and transparently study the specific experimental conditions and the effects they have on the dependent variables as controlled as possible. This enables us to derive a clear and general conclusion about the relationship between the dependent and independent variables that may lead to new insights or arguments regarding the clarification of the issue under scrutiny. Surely the research strategy must be to perform a variety of mutually different experiments in order to approach the real-life situation. But we start simple and might therefore use the result of this study as the basis to explore more complex situations in a later stage.

Our purpose in this paper is to report on an experiment of negotiations in a laboratory setting between a public authority and a private real estate developer with regard to a property development process. This experiment attempts to observe and analyse actors' strategic decision making behaviour in the negotiation process. For this experiment we make reference to game-theoretical experiments carried out in other fields of study. The negotiation is about the developer's contribution to the costs of public works in the case of public infrastructure provision, assuming that this public infrastructure is beneficial to the private developer's investments in a specific land and property development project. The issue of value capturing in land and property development raises discussions in almost every country (Van der Krabben, Needham 2008). The outcome of the negotiations however will very much depend on the institutional context (planning legislation) in which the negotiations take place. We use the Dutch plan- ning system and its specific institutional settings for land and property development as the context for the experiment in this paper.

This paper is structured as follows. In section 2, the set up of the experiment is discussed which include the general framework for the experiment, the context of the experiment which related to land and real estate development process, the conceptualisation of general problems that are investigated in the experiment including some hypotheses for the analysis, and then followed by an explanation about the design of the experiment. Section 3 provides the results of the experiment and then they are discussed in section 4 . Finally, section 5 presents the conclusions that can be derived from our experimental study.

\section{THE EXPERIMENT}

\subsection{General framework}

The negotiation experiment in this study has been developed based on the model of bilateral sequential bargaining over the distribution of a certain value. In this kind of experimental models, the bargaining is limited to a certain period of time in which the bargainers have the opportunity to make alternate offers. Each of the bargainers can make an offer which the other may accept or reject. If the offer is accepted, the bargaining process ends and both bargainers receive their payoffs based on the accepted offer. If the offer is rejected before the negotiation time has ended, the other bargainer can make a new offer. The bargaining results in disagreement if no offer has been accepted when the bargaining time is ended. In that case both bargainers will receive nothing.

Various studies of this kind of experiment have reported different results, sometimes quite contradictive to one another especially regarding the issue of fairness. For instance, the work of Roth et al. (1981) confirms that bargainers tend to seek a fair result by agreeing to divide the outcome of the negotiation in equally-sound value. This result is common among studies in social psychology (see e.g. Major 1994; Jost et al. 2004). On the other hand, the work of Guth et al. (1982) suggests that the bargainers basically cannot be expected to persuade a fair division of the negotiation outcome.

The issue of fairness has been an important topic of long debates in economics. The traditional economic assumption of the profit-maximizing agents clearly expresses that fairness is irrelevant to economic analysis. The non-fairness assumption 
implies a resistance to explanations of economic actions in moral terms. Reality, however, provides many examples indicating that people are also driven by fairness considerations and act more cooperative than is assumed in the standard free actions of self-interested agents approaches. In this study, we also attempt to investigate the issue of fairness specifically in a negotiation process between a public authority and a private developer in a land and real estate development project. More about this issue will be explained in section 2.3.

It should be noted that most of the bargaining experiments, including those that are mentioned above, have two general features. First, they were carried out in a context-neutral setting by involving "general" participants (usually students, sometimes specifically from economics departments in a university), which basically is reasonable since the main purpose of those studies was to analyse the strategic economic behaviour of subjects in general bargaining situations. In our study, the context is more important than has been suggested in some previous general negotiation studies. The reason for this is that in our experiment, our concern is primarily with the negotiation about the extent to which the costs of public infrastructure provision related to land and property development are shared between the public and the private sector. We particularly specify this context within the Dutch institutional setting. Typical for land and property development in the Netherlands is the municipalities' pro-active land policy and, in that context of active land policy, the application of the so-called building claim model. For that reason, in this study we use subjects from the field to ensure that the context could be brought into the experiment by the participants. More explanation about this context will be provided in section 2.2.

The second general feature in a general bargaining experiments is that the time period usually is limited to some definitive stages in exchanging offers that should be made by the bargainers. Mostly, they even have only one stage of bargaining as in the ultimatum bargaining game ${ }^{1}$. In the experiment conducted in this study, we only impose a time limit to do the bargaining process,

\footnotetext{
1 The ultimatum bargaining game is a form of bargaining in which two players interact to decide how to divide a sum of money that is given to them. The first player proposes how to divide the sum between the two players, and the second player can either accept or reject this proposal. If the second player rejects, neither player receives anything. If the second player accepts, the money is split according to the proposal. The game is played only once so that reciprocation is not an issue.
}

but there is no limitation on how many stages the bargainers can make in exchanging offers.

\subsection{Context of the experiment}

In order to pro-actively implement their planning goals, Dutch municipalities often actively purchase all required land from its original landowners to be developed as officially stated in a land use plan. After that the municipality readjusts the parcels into building plots suitable for the desired development, then services the land by providing necessary infrastructures and utilities, and finally releases the parcels to developers and/or end users (Van der Krabben, Jacobs 2013). Municipalities charge full market prices for the building plots (based on residual valuations) and they use the income from the building plot sales to cover the costs of the public infrastructure provision.

A condition for the successful implementation of this active land policy is that the municipality must assemble all land in the plan area, to be able to gain sufficient income from the building plot sales to cover the public infrastructure costs. In some situations ${ }^{2}$, however, private developers that have an intention to build houses or any other real-estate development have been able to acquire land in the plan area before the municipality was able to do so. In those cases, a so-called building claim model or strategy has been (and still is) applied. The strategy involves an agreement between the private developer and the municipality that the private developer sells his land to the municipality (so that the municipality has complete ownership of the land in the plan area) without trying to make any profit (the selling price is usually very similar to what the private developer had previously paid for it), but under the condition that the private developer holds a building claim that guarantees him both the first right to buy the serviced land from the municipality and a building permit to build real estate properties on it. Especially in the case of residential area development, the building claim model also involves an agreement between the developer and the municipality regarding the number and type of houses that can be built on the land ${ }^{3}$ and the infrastructure, public utilities and public space that will be pro-

\footnotetext{
2 For reasons that we leave out of this paper. See Needham (2007) and Van der Krabben, Jacobs (2013) for a detailed explanation of the developments that took place on the Dutch land market.

3 The number of houses that the private developer will be allowed to build usually depends on the size of its land position (roughly, 1 hectare of land will give a building claim of around 30 houses).
} 
vided (at the cost of the municipality). Sometimes, the municipality and private developer may agree that the building plots that will be sold to the private developer are located somewhere else in the planned development area (not exactly the same location, where the private developer previously held its land position). By participating in the building claim model, the private developer will benefit from a high-quality location, 'provided' by the municipality, for profitable property development and, at the same time, excludes competitors from the market (Altes 2006). Usually, the above negotiations take place with respect to very large residential developments (5,000 to even 25,000 houses built on one location). Various private developers - and also housing associations - may hold land positions here and also the municipality itself usually has been able to acquire land. The municipality will negotiate with each of the land holding private developers individually regarding the sale of "raw land" from the private developer to the municipality and the sale of serviced building plots with the building claim from the municipality to the same private developer. In those situations, the negotiation between the municipality and the private developer does not only concern the price of the raw land to be paid for the land to be purchased by the municipality, but also the price of serviced land to be sold back by the municipality to the land developer. The latter negotiation - on which our experiment will be focused on - can be considered as a value capturing negotiation: the higher the price the private developer agrees to pay for the serviced building plots, the better the municipality is able to cover its costs of public infrastructure provision. Those negotiations have been characterised as a lengthy processes and in many times resulted in disagreement which eventually drove the development project into a failure (Van der Krabben, Needham 2008; Muñoz-Gielen 2011).

\subsection{Problem conceptualisation and hypothesis}

As mentioned earlier, this experiment concerns about observing, through a simulation, actors' strategic decision making behaviour in a negotiation process also with regard to the issue of fairness that occurs specifically between a municipality and a private developer over the price of serviced land in land and real estate development process based on the Dutch building claim model. Fairness is not an easy issue to define because what counts as fair in different societies and different situations might vary as much as the discrepancy of humans preferences and behaviours. In many social systems fairness might also be perceived as a form of justice and there are many types of justice principles that can be identified in social science literature (Cook, Hegtvedt 1983). Among those principles, we can make a general distinction between equity and distributive principles of justice or fairness. The equity principle involves notions of exchange and is defined as the equivalence of the ratio of outcome and inputs of all parties involved in the exchange (Adams 1965). Suppose there are only two parties (A and B) engaged in the exchange of two valued resources, for instance $x$ that is provided by A and $y$ that is provided by B. In this case, $x$ is perceived as A's input to exchange and also as B's outcome, while $y$ is perceived as B's input and A's outcome. The equity principle is then said to exist if the ratio of outcome and input, for both $\mathrm{A}$ and $\mathrm{B}$, is equal.

The second principle of justice, i.e. the distributive principle, concerns general fairness in allocation situations. Allocation occurs when one party tries to distribute a value - could be as a reward, a resource, rights, obligations, etc. - to an array of recipients. As argued by Eckhoff (1974), both exchange and allocation processes can actually be combined, as he defined exchange as a special class of allocation in which the distribution mechanism is the two-way transfer of mutual benefits. The form of equality as in the equity principle is therefore also upheld in the distribution process which then can be conceived as the equality principle. Homans (1958) emphasized this rule of equality in a distribution mechanism as a condition of equilibrium. In this study, we also use this notion of equal distribution to analyse fairness. With regard to the negotiations between a municipality and a private developer over the price of serviced land in property development, we therefore attempt to investigate whether both parties are concerned about fairness. This could be confirmed by an equilibrium of the negotiation outcome based on the equal distribution principle.

In addition to the principle above, many studies have demonstrated that actors' preferences for fairness are also related to the availability of information. For instance, Hoffman et al. (1994) and Straub and Murnighan (1995) have found in experiments that agents or bargainers tend to made much smaller offers when they know that their opponents' cannot observe their actions. They also confirm that bargainers have a tendency to agree on a fair outcome when they have information 
about the amount being divided in the bargaining situation. In this study, we use this contention as a hypothesis for the observation in the experiment, hence we expect that with increased availability of information, the parties in a bargaining process will be more inclined to fairness. Furthermore, we might also reasonably expect that, prior to having a fair outcome, the availability of information will also affect the bargainers' possibility to reach an agreement and to increase negotiation efficiency, in terms of time or stages needed for the negotiation. The hypotheses of this study can therefore be formulated as follow:

$\mathrm{H}_{1}$ : The more available the information is, the more plausible it will be that the bargaining parties will reach an agreement.

$\mathrm{H}_{2}$ : The more available the information is, the lesser number of stages of negotiation will be needed by the bargaining parties to reach an agreement.

$\mathrm{H}_{3}$ : The more available the information is, the more inclined the bargaining parties will be to reach a fair agreement.

\subsection{Experimental design and procedures}

Our experiment deals with the negotiation that takes place between a municipality and a landholding private developer. The negotiation is specifically concerning the price per $\mathrm{m}^{2}$ paid for serviced building plots as part of a greenfield residential development. The process of the negotiation takes place, as we explained earlier, at the time that the private developer agrees to sell the raw land that he owns to the municipality. As an exchange for the building right to claim back the land by buying it from the municipality, the private developer must pay this price at a certain time in the future, after the land has been serviced and public infrastructure has been provided, when he/she can really start to build houses. Although the building claim model is quite common now in residential development projects in the Netherlands, we are aware of the fact that it can still be quite complicated to fully understand it by non-involved participants in the experiment. In order to make sure that this context for the experiment is taken into account, we therefore have involved only planning and land and property development professionals as participants in the experiment. These participants all worked with (different) urban planning consultancy companies in the Netherlands and have experience with active land policy and the implementation of the building claim model. Since it is also not something uncommon in the Netherlands that municipalities as well as private developers uses the service of consultant to represent them in negotiation processes as illustrated in our experiment, all participants can freely choose their role in the experiments either as a municipality or a private developer. The participants were invited through an open invitation to their company. A total of 20 participants were involved in this experiment who performed 90 negotiation processes (see section 3 ).

The experiment was developed based on linear bilateral distributive negotiation model of Raiffa (1982). In this model, there are only two players involved. Let's assume these players are a seller $(S)$ and a buyer $(B)$. Both player should at least have the information about their own reservation price (namely $R_{S}$ and $R_{B}$ for $S$ and $B$ respectively) to be able to make a negotiation. For $S$, this reservation price means the minimum price he/ she could accept; and oppositely for $B$, it means the maximum price he/she could afford. A negotiation can therefore never have an agreement if $R_{S}>R_{B}$. The positive interval between $R_{S}$ and $R_{B}$, i.e. $R_{B}-R_{S}$, expresses the zone of possible agreement (ZOPA). In the case of equal power position between $S$ and $B$, the equilibrium is defined by the equal division of the difference between the reservation prices of $S$ and $B$ or $\left(R_{B}-R_{S}\right) / 2$, i.e. the middle value of ZOPA.

In order to apply this bargaining in an experiment, as mentioned earlier, we went beyond the common bargaining games experiments which usually involve only one exchanging stage, by imposing a limitation only on the time of bargaining and not on the stages of bargaining. The bargainers can thus make as many sequential exchanging offers as necessary to them within the time limits for the negotiation. In addition to that, we also have extended the experiment into three different negotiation games distinguished by the information that is available to the participants: a negotiation game with incomplete information (Game 1), a negotiation game with asymmetric information (Game 2), and a negotiation game with complete information (Game 3). By playing these three different games, we expect to find differences in the bargainers' decision behaviour related to the availability of information.

The Session was conducted in the NSM Decision Lab at Radboud University Nijmegen ${ }^{4}$, where subjects were seated in isolated cubicles in front of computer terminals that were connected through a computer network. In this experiment, the subjects were thus doing the negotiations via comput-

4 http://www.ru.nl/fm/decisionlab/ 
ers anonymously without knowing their opponents and without having any opportunity to communicate with them. With this setting, we could have more control on the results of the experiment by minimising the influence of such emotional factors including personal persuasion or intimidation as well as any consideration about external issues, and hence we could expect that the bargainers would make their decisions as best as they can based on their experiences and knowledge as the real experts and professional from the field.

The experiment was programmed using the $z$ Tree software (Fischbacher 2007). The program assigned the subjects in a random way to play either a role as a municipality or a private developer and coupled them into ten groups. Once a subject is assigned to play a certain role, he/she sticks to this role for the whole experiment. Moreover, three treatments or games were run accordingly to the three different negotiation games mentioned earlier. Each game was run for three rounds, hence there were nine negotiations rounds in total. In each round, the program also randomly changed all the groups; therefore each subject made the negotiation with a different opponent. The negotiation time in each round was limited to six minutes. At the end of each round, all subjects were asked to written down their motivations in having or not having an agreement via the computer. It should be noted that the six minutes time in this experiment is chosen arbitrarily to give a limit to the negotiation process. However, in this study we focus on the information condition and the payoff; time limit is then only treated as a constant and not as an experimental condition.

All subjects were provided with relevant financial information targeted to their role, based on hypothetical land development projects. Based on the three different games that were played in this experiment, three different availability levels of financial information were given to the subjects as if they were involved in three different land development projects. The financial information for the municipalities was about the total costs to prepare the land with necessary public infrastructures and also the reservation price or the minimum price that they could accept from the private developer to avoid financial loss from the negotiation ${ }^{5}$. The financial information for the private developers contains the costs for developing the land with houses as well as the expected reve-

\footnotetext{
5 A loss will occur when the total revenues of the sale of the building plots is lower than the total costs for the municipality, consisting of the acquisition costs for the raw land and the costs for the public works.
}

Table 1. Reservation prices of bargainers

\begin{tabular}{llll}
\hline & Game 1 & Game 2 & Game 3 \\
\hline $\begin{array}{l}\text { Private developer's } \\
\text { reservation price }\end{array}$ & 350 & 300 & 320 \\
$\begin{array}{l}\text { Municipality's } \\
\text { reservation price }\end{array}$ & 260 & 240 & 280 \\
\hline
\end{tabular}

nues from selling the houses to end-users and the reservation price or the maximum price they could accept to buy the serviced land from the municipality in order to avoid financial $\operatorname{loss}^{6}$. It should be noted here that the reservation price of municipalities will always be lower than the private developers' reservation price in order to make it possible for both parties to make an agreement. The reservation prices of each bargainer in each game are given in Table 1.

Expected profits for the municipality and the private developer were also included in their corresponding financial information, to give the bargainers some ideas about the price they would like to offer or accept in the negotiation. The residual valuation method which is usually employed in the financial appraisal of land and property development projects were used here to calculate the expected profits (Morley 2002). The expected profit is expressed as a certain percentage from the total development costs. These profit percentages are considered in this experiment as the utility of the negotiation outcome to the corresponding bargainers. All participants were aware that in the end of the session, real money would be offered to them in proportion with the profit they made in the experiment. By doing this, we expected that they would be playing their role more seriously in the experiment, showing similar behaviour as they do in real life situations.

The level of financial information that was available to the players varied in each game. All subjects in Game 1 were only provided with the financial information accordingly to his/her role. In Game 2, the subjects who play as private developers had both the financial information concerning their own position and concerning the municipalities' position, while the subjects who played as municipalities only had access to the financial information concerning their own position. In Game 3, all subjects were provided with both the financial information regarding their own position and their opponent's position.

6 A loss will occur when the total revenues of the sale of the houses is lower than the total costs for the private developer, consisting of the acquisition costs of the serviced building plots and the building costs. 


\section{RESULTS}

In this section, we present the data obtained from the experiment. The observation focused on three main features of bargaining outcomes, including (1) the final prices that were set in the negotiations with an agreement, (2) the number of negotiations that reached an agreement and that did not, and (3) the number of stages to reach that agreement. There were 30 negotiations for each game, and thus in total there were 90 negotiation results from this experiment.

\subsection{Number of agreements}

The results of the observation regarding the number of negotiations that reached an agreement or not are presented in Table 2. It shows that the number of disagreements increases from Game 1 to Game 3. Intriguingly, in round 1 of Game 3, there were only two groups out of ten that were able to reach an agreement. With this result, we should reject our first hypothesis $\left(H_{1}\right)$ that says the more available the information, the more plausible it will be that the bargaining parties will reach an agreement. In other words, the results of the experiment have gave us an interesting understanding that apparently the availability of information does not necessarily make the bargainers easier to reach an agreement. On the contrary, it apparently makes it harder for them to do so.

In order to statistically prove that the differences in the availability of information in the games significantly cause the different results in reaching an agreement or not, we applied Cochran's $Q$ test from non-parametric statistics, since we do not have any assumption about the distribution of the data. The results of the test for the three games are given in Table 3. Intriguingly, with $\mathrm{a}=0.05$, the test confirms that the availability of information affects the decision of bargainers to reach an agreement only for round 1, but not for the whole game. These results will be discussed in more detail in section 4 .

\subsection{Negotiation stages}

Regarding the number of negotiation stages, average numbers clearly decline from Game 1 to Game 3 (Fig. 1). It means that we should accept our second hypothesis $\left(\mathrm{H}_{2}\right)$ that says the more available the information, the lesser number of stage negotiation needed by the bargaining parties to reach an agreement. Assuming that the negotiation can be considered as more efficient if an agreement can be reached using less stages, these results may confirm that the availability of information to the bargainers does increase the efficiency of the negotiation.

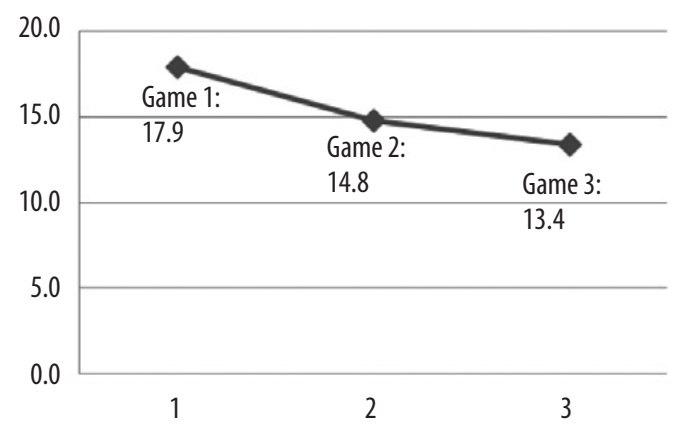

Fig 1. Average of negotiation stages in each game

Table 2. Number of negotiations with and without agreements

\begin{tabular}{|c|c|c|c|c|}
\hline & & \multicolumn{3}{|c|}{ Number of negotiations } \\
\hline & & With agreement & Without agreement & Total \\
\hline \multirow[t]{4}{*}{ Game 1: incomplete information } & Round 1 & 7 & 3 & 10 \\
\hline & Round 2 & 7 & 3 & 10 \\
\hline & Round 3 & 7 & 3 & 10 \\
\hline & Total & 21 & 9 & 30 \\
\hline \multirow[t]{4}{*}{ Game 2: asymmetric information } & Round 1 & 8 & 2 & 10 \\
\hline & Round 2 & 5 & 5 & 10 \\
\hline & Round 3 & 4 & 6 & 10 \\
\hline & Total & 17 & 13 & 30 \\
\hline \multirow[t]{4}{*}{ Game 3: complete information } & Round 1 & 2 & 8 & 10 \\
\hline & Round 2 & 6 & 4 & 10 \\
\hline & Round 3 & 7 & 3 & 10 \\
\hline & Total & 15 & 15 & 30 \\
\hline
\end{tabular}


Table 3. Cochran's Q test results

\begin{tabular}{|c|c|c|c|c|c|c|}
\hline & \multicolumn{2}{|l|}{ Round 1} & \multicolumn{2}{|l|}{ Round 2} & \multicolumn{2}{|l|}{ Round 3} \\
\hline & $\begin{array}{l}\text { With } \\
\text { agreement }\end{array}$ & $\begin{array}{l}\text { No } \\
\text { agreement }\end{array}$ & $\begin{array}{l}\text { With } \\
\text { agreement }\end{array}$ & $\begin{array}{l}\text { No } \\
\text { agreement }\end{array}$ & $\begin{array}{l}\text { With } \\
\text { agreement }\end{array}$ & $\begin{array}{l}\text { No } \\
\text { agreement }\end{array}$ \\
\hline Game 1: incomplete information & 7 & 3 & 7 & 3 & 7 & 3 \\
\hline Game 2: asymmetric information & 8 & 2 & 5 & 5 & 4 & 6 \\
\hline Game 3: complete information & 2 & 8 & 6 & 4 & 7 & 3 \\
\hline Cochran's Q & 6.2 & & 0.857 & & 2.25 & \\
\hline $\mathrm{df}$ & 2 & & 2 & & 2 & \\
\hline Asymp. Sig. & 0.045 & & 0.651 & & 0.325 & \\
\hline
\end{tabular}

\subsection{Final prices}

Concerning the agreed final prices that came out of the negotiations, it was investigated whether the prices could confirm or preclude the equilibrium, especially one that is expected to promote an equal division of negotiation outcome. The equilibrium in this experiment is calculated based on a refinement of Raiffa's approach (1982). While Raiffa's approach would calculate the equilibrium price by equally dividing the difference between the municipality's and private developer's reservation prices, in our experiment we calculated the equilibrium in each game by finding the price that yields an equal utility for both players $\left(P_{E}\right)$ which, as mentioned earlier, is the profit percentage to the corresponding total costs of both the municipality and the private developer.

The general description of the final prices of each game that were observed from the experiment as well as their corresponding expected equilibrium prices and the bargainers' utilities at the equilibrium prices are given in Table 4. Furthermore, the average values of the agreed final prices from round to round for Game 1 to Game 3 are given in Figure 2 to Figure 4 respectively, showing the tendency of the agreed final prices towards their corresponding equilibriums.

From Table 4, we can find that the average of final prices of Game 2 and Game 3 are very close to their equilibriums compared to Game 1 which means that the propensity of the bargainers to seek a fair result is more apparent in these two games. In order to prove the significance of the

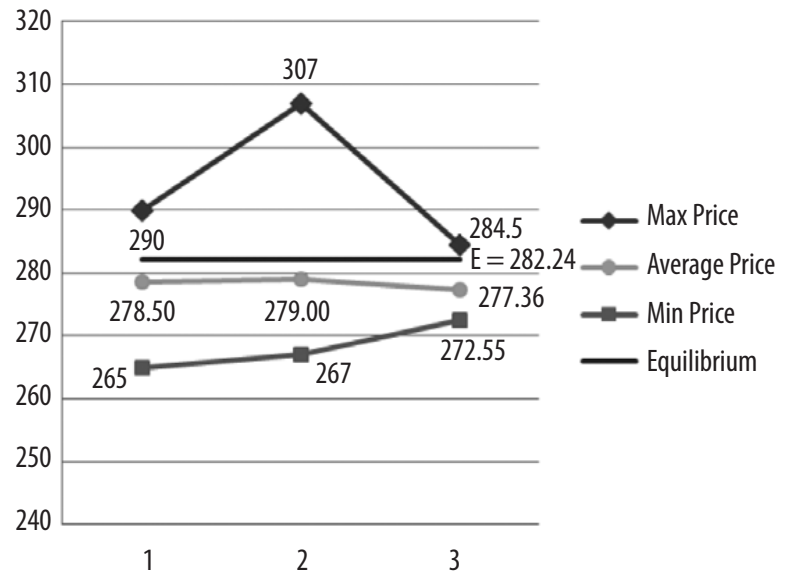

Fig 2. Final prices of Game 1 for each round

agreed final prices in each game related to its corresponding equilibrium, we conducted the Wilcoxon signed-rank test from non-parametric statistics (again, because we do not have any assumption about the distribution of the data). The results of the test indicate that, at the $\mathrm{a}=0.05$ level of significance, there is sufficient evidence to claim that in Game 2 and 3 the bargainers had significantly settled an agreement at the equilibrium prices (Table 5). However, although we cannot conclude that in the Game 1 the bargainers were reaching the equilibrium, its significance value still suggests that it is very close, because the value is exactly in the threshold of rejecting the claim.

Meanwhile from Figure 2 to Figure 4, we cannot draw a clear conclusion whether the average final prices from round to round in each game have

Table 4. Final prices for each game

\begin{tabular}{lllllllll}
\hline & $\mathrm{N}$ & $\mathrm{Min}$ & $\mathrm{Max}$ & Average & $\begin{array}{l}\text { Std. } \\
\text { Dev. }\end{array}$ & $\begin{array}{l}\text { Equilibrium } \\
\text { prices }\left(P_{E}\right)\end{array}$ & $\begin{array}{l}\text { Bargainers' } \\
\text { utilities at } P_{E}\end{array}$ \\
\hline Final prices of Game 1: incomplete information & 21 & 265.00 & 307.00 & 278.29 & 9.61 & 282.24 & 8.6 \\
Final prices of Game 2: asymmetric information & 17 & 245.00 & 269.00 & 257.50 & 6.78 & 257.61 & 7.3 \\
Final prices of Game 3: complete information & 15 & 291.00 & 294.00 & 293.00 & 0.91 & 293.13 & 4.7 \\
\hline
\end{tabular}




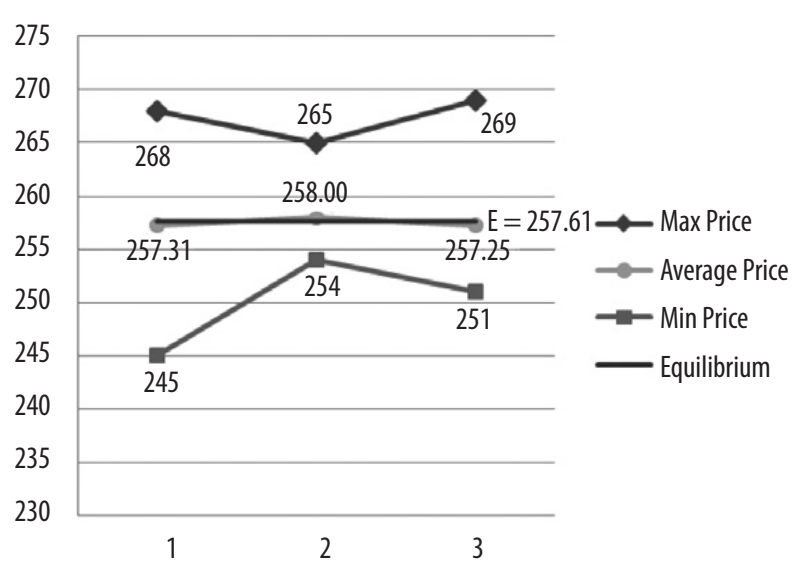

Fig 3. Final prices of Game 2 for each round

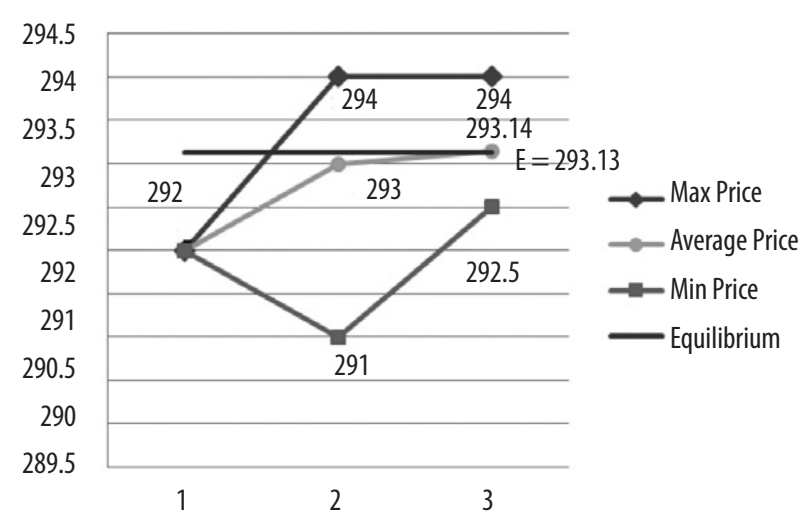

Fig 4. Final prices of Game 3 for each round

a tendency to move closer to their corresponding equilibrium or not, except perhaps in Game 3. In Game 3, the trend clearly moves towards the equilibrium, while even the average final prices almost equals the equilibrium in round 3. However, although for Game 2 the trend is not very clear (Fig. 3), it is interesting to see that still the average final prices for this game are exceptionally close to the equilibrium in all rounds. As the results of this experiment confirm that in all three games, the outcomes of the bargaining are close to the equilibrium. This means that the bargainers are trying to obtain the fair outcome regardless the availability of information to them. We therefore do not have a strong argument to accept our third hypothesis $\left(H_{3}\right)$ that says the more available the information is, the more inclined the bargaining parties will be to reach a fair agreement.

Table 5. Wilcoxon signed-rank test results

\begin{tabular}{llll}
\hline & $\begin{array}{l}\text { Game 1: } \\
\text { incomplete } \\
\text { information }\end{array}$ & $\begin{array}{l}\text { Game 2: } \\
\text { asymmetric } \\
\text { information }\end{array}$ & $\begin{array}{l}\text { Game 3: } \\
\text { complete } \\
\text { information }\end{array}$ \\
\hline Z & -1.964 & -0.071 & -0.573 \\
Asymp. Sig. & 0.05 & 0.943 & 0.567 \\
\hline
\end{tabular}

\section{DISCUSSION}

As we mentioned above, the results of the experiment show that the number of disagreements increase from Game 1 to Game 3. This suggests that in the first iteration, the bargainers find it more difficult to reach an agreement when they have more information regarding the financial conditions of their opponents. These results are in contrast with results from earlier research, showing instead a positive effect of the availability of information to the extent in which the bargainers' can reach an agreement (e.g.: Hurwicz 1972; Selten 1978; Roth, Murnighan 1982). Referring to one of the fundamental assumptions in game theory - a rational play depends on the availability of the relevant information regarding both the structure of the game and the utility function of the players - we would assume that an agreement, as a rational outcome of the bargaining process, might be expected to transpire in this experiment when the bargainers have a common knowledge about complete information. The evidence that was found in this experiment may therefore suggest that the bargainers act less rational when they have complete information. The subjects in the experiment motivated their tendency not to reach an agreement anymore after having full information about their opponents' financial position by arguing that they tend to distrust their opponents. With full information about their opponents' financial situation they were able to find out that their opponents have asked "too much". Their response was to punish their opponents by increasing their bids as well, considering this as a fair response even though these responses may lead to disagreement. We assume that in the situation of incomplete information, the trust problem does not exist - or at least to a lesser extent - simply because the subjects do not really know what is "too much" for the opponent. However, as we found that the effect of information availability to the bargainers' propensity to reach an agreement is not significant in the second and the third iteration of the bargaining process, we might conclude that the repetition of the bargaining process gives the bargainers an equal opportunity in all the three games to learn from their previous attempts, in order to have a better outcome by reaching an agreement.

It is also interesting to note that, although the observation of the number of agreements/disagreements shows that the subjects were evidently not behaving in a rational way, the results of the experiment considering the final prices prove other- 
wise. Regardless the availability of information, in each game the bargainers tended to be more rational in reaching a fair outcome, demonstrated by the fact that the results were getting closer to the corresponding equilibrium. This claim is not only confirmed by the statistical test, but also by the subjects' explanations in which they stated that they had indeed the intention to look for a fair outcome. They also stated that the fact that they could not communicate their intentions to one another during the experiment made it difficult for them to assess their opponent's intentions. Since the only way to communicate in this experiment is by offering a bid, the bargainers found it hard to trust their opponents that they wanted to reach a fair outcome (i.e. the equilibrium) from the negotiation as well, when the opponent made an offer that is too far away from the equilibrium, which in the end could ruin the negotiation. These findings might permit us to speculate that due to the lack of communication between the bargainers, the more information that is available to them, the more suspicious they are in trusting their opponents.

\section{CONCLUSIONS}

This paper has reported an experiment about three different two-person bargaining processes in which different levels of financial information availability are used as stimuli in a laboratory setting. Specific contexts together with specific subjects were used in the experiment in order to give us a possibility to specifically observe the bargaining process in land and property development, particularly regarding value capturing for public infrastructure provision.

The results of the experiment have confirmed that, with the specific contexts introduced to the negotiation, both the availability of information and the (lack of) communication opportunities play an important role especially to the bargainers' propensity to reach an agreement and to the efficiency of the bargaining. We have learned from the present study that the more information is available to the bargainers, the more difficult it is to them to reach an agreement, particularly in a situation that communication is restricted. This study also provides evidence that it is in the bargainers' concerns to reach an agreement with a fair outcome, which is defined here as the equilibrium, regardless the availability of the information to them. A fair outcome, in the context of the experiment, means that private developers from their side are willing to pay a good price for the building plots (thus contributing to the costs of public infrastructure provision) and that municipalities accept the commercial drive of the private developers to make a profit out of the development. A bit speculating on this outcome, one could argue that legislation for value capturing in land and property development - available in some countries, including the Netherlands, but not in other countries - is perhaps not necessary, since municipalities and private developers often have a mutual interest in reaching an agreement about planned developments, including private sector contributions to public infrastructure costs.

Although this study may provide some insights about the strategic negotiation behaviour of stakeholders in land and property development processes, the conclusions should still be received with much caution. To achieve a more robust general conclusion, it is important to run the experiment in many repetitions with more variation in amount and nature of information, while at the same time, more contextual factors should be taken into account in the bargaining process to make it closer to the real world. We are thus fully aware about the limitations of this study. For instance, we used a specific timeframe for the negotiation in the experiment which might have an influence to the players' behaviour and also the results of the negotiation. In this particular study we did not specifically focus our analysis on time variable; in future studies, it might be an issue to include this focus too. In addition to that issue, the results of this experiments might be influenced by the specific Dutch context. Therefore, in the future, the same research can be conducted in different countries with different cultures and contexts to enable an international comparison and generate more general conclusions. Another issue concerns the computer-based methodology that we deliberately and fully consciously used in this experiment to avoid the influence of emotional factors including personal persuasion or intimidation as well as any consideration about external issues which certainly play an important role in real-life negotiation processes. Surely these variables have their own right to be analysed which might be an important agenda for future research.

\section{ACKNOWLEDGMENT}

The authors would like to thank Ms. Qing Ma, M.Sc for her help with the programming for the experiment and Ms. Tessa van de Zande, M.Sc. for her help with the organization of the experiment. 


\section{REFERENCES}

Adams, J. S. 1965. Inequity in social exchange, Advance Experimental Social Psychology 2: 267-299. http:// dx.doi.org/10.1016/S0065-2601(08)60108-2

Adams, D. 1994. Urban planning and the development process. London: UCL Press.

Altes, W. K. K. 2006. Stagnation in housing production: another success in the Dutch 'planner's paradise'?, Environment and Planning B: Planning and Design 33(1): 97-114. http://dx.doi.org/10.1068/b31192

Arentze, T.; Timmermans, H. 2003. A multiagent model of negotiation process between multiple actors in urban developments: a framework for and results of numerical experiments, Environment and Planning B: Planning and Design 30: 391-410. http://dx.doi. org/10.1068/b12950

Bazerman, M. 1986. Judgment in managerial decision making. New York: Wiley.

Binmore, K.; Swierzbinski, J.; Tomlinson, C. 2007. An experimental test of Rubinstein's bargaining model, ELSE Working Paper \#260. London: ESRC Centre for Economic Learning and Social Evolution.

Black, R. T.; Diaz III, J. 1996. The use of information versus asking price in the real property negotiation process, Journal of Property Research 13(4): 287-297. http://dx.doi.org/10.1080/095999196368808

Cook, K. S.; Hegtvedt, K. A. 1983. Distributive justice, equity, and equality, Annual Review of Sociology 9(1): 217-241. http://dx.doi.org/10.1146/annurev. so.09.080183.001245

Eckhoff, T. 1974. Justice: its determinants in social interaction. Rotterdam: Rotterdam Press.

Ennis, F. 1997. Infrastructure provision, the negotiating process and the planner's role, Urban Studies 34(12): 1935-1954. http://dx.doi.org/10.1080/0042098975150

Farthing, S.; Ashley, K. 2002. Negotiations and the delivery of affordable housing through the English planning system, Planning Practice \& Research 17(1): 45-58. http://dx.doi.org/10.1080/02697450220125078

Fischbacher, U. 2007. Z-Tree: Zurich toolbox for readymade economic experiments, Experimental Economics 10: 171-178. http://dx.doi.org/10.1007/s10683006-9159-4

Guth, W.; Schmittberger, R.; Scwarze, B. 1982. An experimental analysis of ultimatum bargaining, Journal of Economic and Organization 3: 367-388. http:// dx.doi.org/10.1016/0167-2681(82)90011-7

Healey, P.; Purdue, M.; Ennis, F. 1995. Negotiating development: rationales and practice for development obligations and planning gain. London: E \& FN Spon.

Hoffman, E.; McCabe, K.; Shachat, K.; Smith, V. 1994. Preferences, property rights and anonymity in bargaining games, Games and Economic Behaviour 7: 346-380. http://dx.doi.org/10.1006/game.1994.1056

Homans, G. C. 1958. Social behaviour as exchange, American Journal of Sociology 62: 597-606. http:// dx.doi.org/10.1086/222355

Hurwicz, L. 1972. On informationally decentralized systems, in R. Radner, B. McGuire (Eds.). Decision and organization. Amsterdam: North-Holland Press.
Jost, J. T.; Banaji, M. R.; Nosek, B. A. 2004. A decade of system justification theory: accumulated evidence of conscious and unconscious bolstering of the status quo, Political Psychology 25(6): 881-919. http:// dx.doi.org/10.1111/j.1467-9221.2004.00402.x

Major, B. 1994. From social inequality to personal entitlement: the role of social comparisons, legitimacy appraisals, and group memberships, in M. P. Zanna (Ed.). Advances in experimental social psychology 26: 293-355.

Morley, S. 2002. The financial appraisal of development project, in S. Guy, J. Hennebery (Eds.). Development and developers: perspectives on property. Oxford: Blackwell Publishing.

Muñoz-Giellen, D. 2011. Capturing value increase in urban redevelopment: $\mathrm{PhD}$ thesis. Radboud University Nijmegen.

Needham, B. 2007. Dutch land use planning: planning and managing land use in the Netherlands, the principles and the practice. The Hague: Sdu uitgevers.

Ochs, J.; Roth, A. E. 1989. An experimental study of sequential bargaining, The American Economic Review 79(3): 355-384.

Raiffa, H. 1982. The art and science of negotiation. Cambridge, MA: Harvard University Press.

Roth, A.; Malouf, M.; Murnighan, J. K. 1981. Sociological versus strategic factors in bargaining, Journal of Economic Behavior and Organization 2: 153-177. http://dx.doi.org/10.1016/0167-2681(81)90003-2

Roth, A.; Murnighan, J. K. 1982. The role of information in bargaining: an experimental study, Econometrica 50(5):1123-1141. http://dx.doi.org/10.2307/1911866

Ruming, K. J. 2009. Development configurations and planning negotiations: a case of fringe development in Sydney, Australia, Urban Studies 46(7): 14611483. http://dx.doi.org/10.1177/0042098009104576

Selten, R. 1978. The equity principle in economic behavior, in H. Gottinger, W. Leinfellner (Eds.). Decision theory and social ethics: issues in social choice. Dordrecht: Reifel Publishing. http://dx.doi. org/10.1007/978-94-009-9838-4_16

Straub, P. G.; Murnighan, J. K. 1995. An experimental investigation of ultimatum games: information, fairness, expectations, and lowest acceptable offers, Journal of Economic Behaviour and Organization 27: 345-364. http://dx.doi.org/10.1016/01672681(94)00072-M

Thompson, L. 1990. Negotiation behavior and outcomes: empirical evidence and theoretical issues, Psychological Bulletin 108(3): 515-532. http://dx.doi. org/10.1037/0033-2909.108.3.515

Urbanavičienė, V.; Kaklauskas, A.; Zavadskas, E. K. 2009a. The conceptual model of construction and real estate negotiation, International Journal of Strategic Property Management 13(1): 53-70. http://dx.doi. org/10.3846/1648-715X.2009.13.53-70

Urbanavičienė, V.; Kaklauskas, A.; Zavadskas, E. K.; Seniut, M. 2009b. The web-based real estate multiple criteria negotiation decision support system: a new generation of decision support systems, International Journal of Strategic Property Management 13(3): 267-286. http://dx.doi.org/10.3846/1648715X.2009.13.267-286 
Van der Krabben, E.; Needham, B. 2008. Land readjustment for value capturing: a new planning tool for urban development, Town Planning Review 79(6): 651-672. http://dx.doi.org/10.3828/tpr.79.6.4

Van der Krabben, E.; Jacobs, H. M. 2013. Public land development as a strategic tool for redevelopment: reflections on the Dutch experience, Land Use Policy 30: 774-783. http://dx.doi.org/10.1016/j.landusepol.2012.06.002
Weg, E.; Zwick, R. 1999. Infinite horizon bargaining games: theory and experiments, in D. Budescu, I. Erev, R. Zwick (Eds.). Games and human behavior: essays in honor of Amnon Rapoport. Mahwah: Laurence Erlbaum Associates.

Xu, Y.; Skibniewski, M. J.; Zhang, Y.; Chan, A. P. C.; Yeung, J. F. Y. 2012. Developing a concession pricing model for PPP highway projects, International Journal of Strategic Property Management 16(2): 201217. http://dx.doi.org/10.3846/1648715X.2012.688071 